Acta Theriologica $36(1-2): 141$ - 151, 1991.

PL ISSN 0001 - 7051

\title{
Habitat use and diet of the wolf in northern Italy
}

\author{
Alberto MERIGGI, Paola ROSA, Anna BRANGI and Carlo MATTEUCCI
}

Meriggi A., Rosa P., Brangi A. and Matteucci C. 1991. Habitat use and diet of the wolf in northern Italy. Acta theriol. 36: $141-151$.

Habitat use and diet of wolves Canis lupus were examined in a mountainous area in the northern Apennines (northern Italy) from December 1987 to March 1989. Wolf signs were looked for along 22 transects representative of the different habitat types of the study area in order to define seasonal differences in habitat use. Scats were collected and analysed to identify the main food items used by wolves in each season. Changes in range surface area were recorded in different seasons in relation to food availability and territoriality of the wolves. Pastures and bushy areas were selected in all seasons, while mixed woods were used only in autumn and conifer reafforestations in winter and spring. Beech woods and arable land were avoided all year round. The main food items of the wolves were fruit (Rosaceae), livestock and wild boar. Fruit was above all in winter and spring, livestock (sheep and calves) mainly in summer during the grazing period and wild boar all year round. The presence of the wolves in northern Italy is only partially dependent on food sources of human origin but these are of fundamental importance during the period of pup rearing.

Dipartimento di Biologia Animale, Università di Pavia, Piazza Botta 9, 27100 Pavia, Italy

Key words: habitat use, diet, seasonal changes, Canis lupus, Italy

\section{Introduction}

In Europe the ecology of the wolf Canis lupus Linnaeus, 1758 has been poorly studied because of early extinction of the species in most of its historical range with exception of the Russian population (see Bibikov 1985). The remaining populations have in recent years shown a positive trend, with expansion of the range and increase in the number of individuals (Bjärvall 1983, Vóskar 1983, Pulliainen 1985, Genov 1987, Reig et al. 1987, Okarma 1989). The reasons for the recovery of the species mainly seem to be the protection granted by laws, the general expansion of large herbivore populations and adaptability to very different environmental features.

From the eighties on, the wolf in Italy has recolonized several zones of the northern Apennines from which it disappeared in the years following the II World War (Cagnolaro et al. 1974, Boitani 1981, Matteucci 1987). These zones are characterized by a continuous and marked decrease in the resident human population, notable modifications in livestock rearing and a marked recovery of the ungulate populations. At present the wild boar (Sus scrofa) is the main ungulate species, inhabiting all the hilly and mountainous zones of the Apennines (Apollonio et al. 1988). The roe deer (Capreolus capreolus) is also widespread. Other species (Dama dama, Cervus elaphus and Ovis orientalis musimon) are present with small and isolated populations. In central and southern Italy where the wolf had never been extinct, the survival of the species seems to be linked to the high availability of unmanaged garbage dumps (Zimen 
and Boitani 1975, Boitani 1983). On the contrary, this resource is however not available in the northern Apennines so that the study of the ecology of the wolf in these areas and the strategies it has adopted to breed and survive in these habitats is of great interest.

In this paper we analyze the relationship between habitat use and diet through the year.

\section{Study area}

The study area $\left(280 \mathrm{~km}^{2}\right)$ was located in a mountainous zone of the northern Apennines between 800 and $1700 \mathrm{~m}$ a.s.l. (Fig. 1). Mixed woods were $23.9 \%$ of the whole area, beech woods $32 \%$, conifer reafforestations $2.8 \%$, pastures $26.0 \%$ and shrub $8.3 \%$. Cultivated fields were a small part of the study area and they were concentrated around villages. The main tree species were Fagus silvatica, Castanea sativa, Quercus pubescens, Quercus cerris, Osthrya carpinifolia. Fruit trees (Malus sp., Pirus sp., Prunus sp.) were also widespread. Rosa canina was very abundant in shrub and wood edges. Four main streams crossed the study area. Human population has dropped by about $80 \%$ during the last thirty years and at present few villages are permanently inhabited. In the study area the presence of livestock decreased until the eighties; from 1980 pastures were gradually re-used by non-local farmers and consequently livestock has increased. In 1988 1,455 cows, 203 horses and 1,000 sheep grazed in the study area from late May to early October. Grazing was free and calves were born on pastures. Wild boar were abundant in the study area; roe deer and fallow deer were occasionally present.

The presence of free ranging or feral dogs was never been recorded by us or by game keepers and state foresters in the study area. The wolf was the only species of large carnivore present in the region.

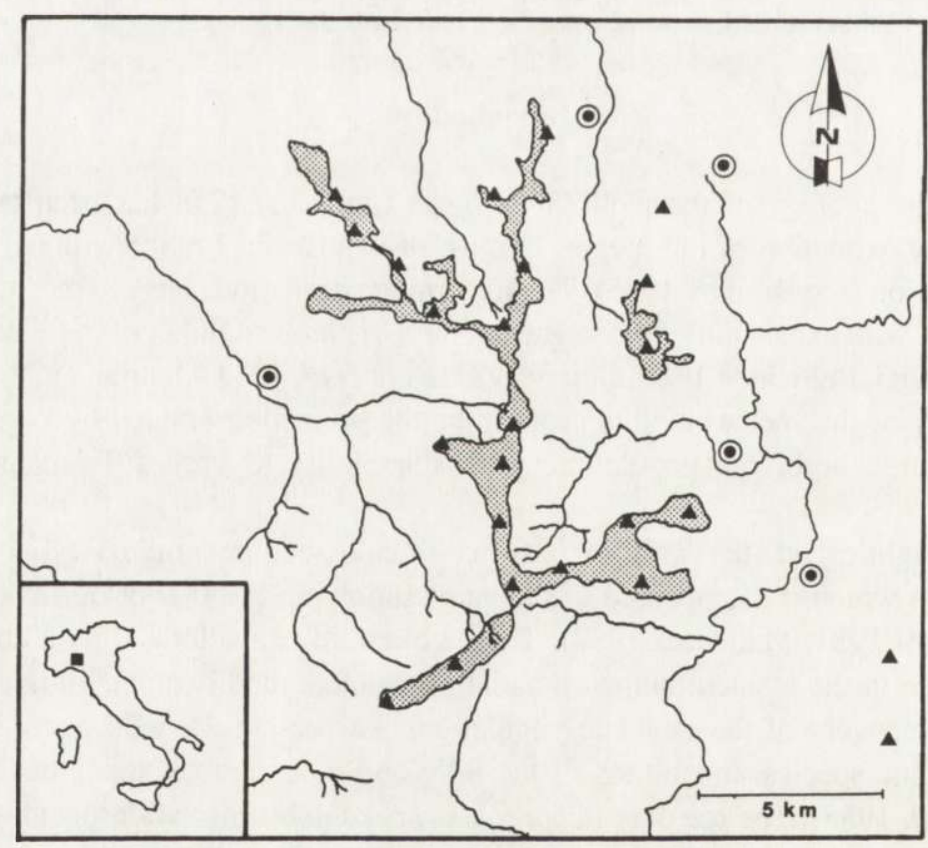

Fig. 1. Study area. Dotted areas - pastures; $\boldsymbol{\Delta}$ - main elevations; $\bullet$ - villages. 


\section{Methods}

Field work was carried out from December 1987 to March 1989. The boundaries of the study area were defined by data collected on the presence of the wolf in the region during the years before research started by interviewing game keepers, state foresters, hunters, stockbreeders and shepards. The study area was searched to check for the current presence of wolves by the wolf-howling method (Harrington and Mech 1982, Strickland 1983, Fuller and Sampson 1988) and by recording tracks, scats and carcasses of preyed animals. All predations on livestock were recorded and verified during the study period. Twenty two transects ( $133 \mathrm{~km}$ in total) were traced and covered in each season. The transects were traced only on footpaths to assure an equal detectability of the wolf signs in the different habitat types. In total the proportions of the different habitat types along the transects were the same as that in the study area. Wolf signs were looked for along the transects and recorded on maps at 1:50,000.

Habitat preferences were analyzed by the following index (Robel et al. 1970):

$$
\mathrm{PI}_{i}=\frac{\mathrm{OPU}_{i}}{\mathrm{EPU}_{i}}
$$

where $\mathrm{OPU}_{i}$ is the observed proportion of usage for the $i$ th habitat calculated as the number of wolf signs found in each habitat over the total number of wolf signs, and $\mathrm{EPU}_{i}$ is the expected proportion of usage for the same habitat type according to its availability. When $\mathrm{PI}<1$ the habitat was avoided, when PI=1 the habitat was used in proportion to availability, and when PI $>1$ the habitat was selected. The diet was studied by the analysis of scats collected along the transects.

The scats were preserved in PVC bags at $-20^{\circ} \mathrm{C}$. They were then washed in water over 3 sieves with decreasing meshes $(0.5$ to $0.1 \mathrm{~mm})$. The prey were identified from undigested remains: chaetae (earthworms), wing-cases, wings, legs and cuticle remains (insects), feathers (birds), hair and bone parts (medium and large sized mammals), hairs and mandibles (small mammals), seeds, epicarp, and leaves (plants). The hairs were washed in alcohol and identified by microscopical observations of cortical scales and medulla (Brunner and Coman 1974, Debrot et al. 1982).

The proportion of prey as they were eaten was assessed for each scat (Kruuk and Parish 1981), and each prey was assigned to one of the following percent volumetric classes: $<1 \% ; 1-5 \% ; 6-25 \% ; 26-50 \%$; $51-75 \% ; 76-95 \% ;>95 \%$. All prey were subdivided into 13 food items (Appendix 1). For each item we calculated: (1) frequency of occurrence (\%), (2) percent volume considering only the scats containing that item, (3) mean volume (\%) considering all the examined scats. The variation of food items in seasonal diets (winter = December to February; spring = March to May; summer = June to August; autumn = September to November) was analized by Kruskall-Wallis and Mann-Whitney U tests. We also calculated the overlap index $\mathrm{C}$ of the seasonal diets by the following formula (Horn 1966, Goszczyński 1986a):

$$
\mathrm{C}=\frac{2 \Sigma \mathrm{x}_{i} \mathrm{y}_{i}}{\Sigma \mathrm{x}_{i}^{2}+\Sigma \mathrm{y}_{i}^{2}}
$$

where: $\mathrm{x}_{i}$ is the proportion of occurrence of the $i$ th item in a season and $\mathrm{y}_{i}$ is the proportion of occurrence of the same item in the compared season. The index varies from 0 (no overlap) to 1 (complete overlap).

The diet breadth in the different seasons was estimated by the B index (Feisinger et al. 1981):

$$
\mathrm{B}=\frac{1}{\mathrm{R} \Sigma \mathrm{p}_{i}^{2}}
$$

were: $\mathrm{p}_{i}$ is the proportion of usage of the $i$ th item and $\mathrm{R}$ is the item number. The index varies from $1 / \mathrm{R}$ (usage of one item only) to 1 when all items are equally used.

The preferences of wolves for the different species of livestock were analysed by the Kolmogorov-Smirnov test on the frequency distributions and by simultaneous Bonferroni confidence intervals of the usage proportions (Neu et al. 1974, Byers et al. 1984). 


\section{Results}

\section{Population status}

Breeding by wolves in the study area was confirmed from 1985 by an illegal killing of a young female aged 5 months. In 1987 another two young females aged 6 months were found illegally killed, and in 1988 we observed two individuals (1 adult together with 1 pup). Over the last four years several observations have been made, ranging from 1 or 2 individuals to a maximum of 5 individuals together. From wolf-howling sessions and track records it resulted that during the 1988 breeding season 2 pairs with pups were present, plus an undefined number of non-breeding wolves.

\section{Habitat preferences}

Habitat selection by wolves showed seasonal changes (Table 1). In winter most of the observations were concentrated in zones quite near to the villages. In this season the wolves

\begin{tabular}{|c|c|c|c|c|}
\hline Habitat & $\begin{array}{l}\text { Winter } \\
(\mathrm{n}=58)\end{array}$ & $\begin{array}{c}\text { Spring } \\
(\mathrm{n}=75)\end{array}$ & $\begin{array}{l}\text { Summer } \\
(n=62)\end{array}$ & $\begin{array}{l}\text { Autumn } \\
(\mathrm{n}=47)\end{array}$ \\
\hline Pastures & 2.0 & 0.2 & 2.2 & 2.5 \\
\hline Mixed woods & 0.3 & 0.3 & 0.3 & 2.5 \\
\hline Beech woods & 0.6 & 0.6 & 0.7 & 0.2 \\
\hline Conifer reafforestations & 3.0 & 3.0 & 0.0 & 0.0 \\
\hline Shrub & 2.3 & 36.6 & 1.7 & 0.7 \\
\hline Arable lands & 0.0 & 0.0 & 0.0 & 0.0 \\
\hline
\end{tabular}

selected pastures, conifer reafforestations and shrub. In spring observations were regularly distributed over the whole study area; only conifer reafforestations and shrub were selected. In summer observations were mainly recorded in the ridges where pastures were located. In this season only pastures and shrubs were selected by wolves, while other habitats were avoided or used in proportion to availability. In autumn pastures and mixed woods were selected. Pastures and shrubs resulted the most used habitat types all year round.

\section{Diet}

We collected 100 fecal samples during the research; 23 were collected in winter, 33 in spring, 14 in summer and 30 in autumn.

The annual diet of the wolves in our study area included 43 kinds of prey, pooled into 13 items (Appendix 1). The Rosaceae fruits and livestock were the most used items, each accounting for about $25 \%$ of the total diet (Fig. 2). Other important items by volume were the wild ungulates (mainly wild boar) and small rodents, and by frequency of occurrence other vegetable matter (other fruits and grasses) and small rodents again. Insects (grasshoppers, 


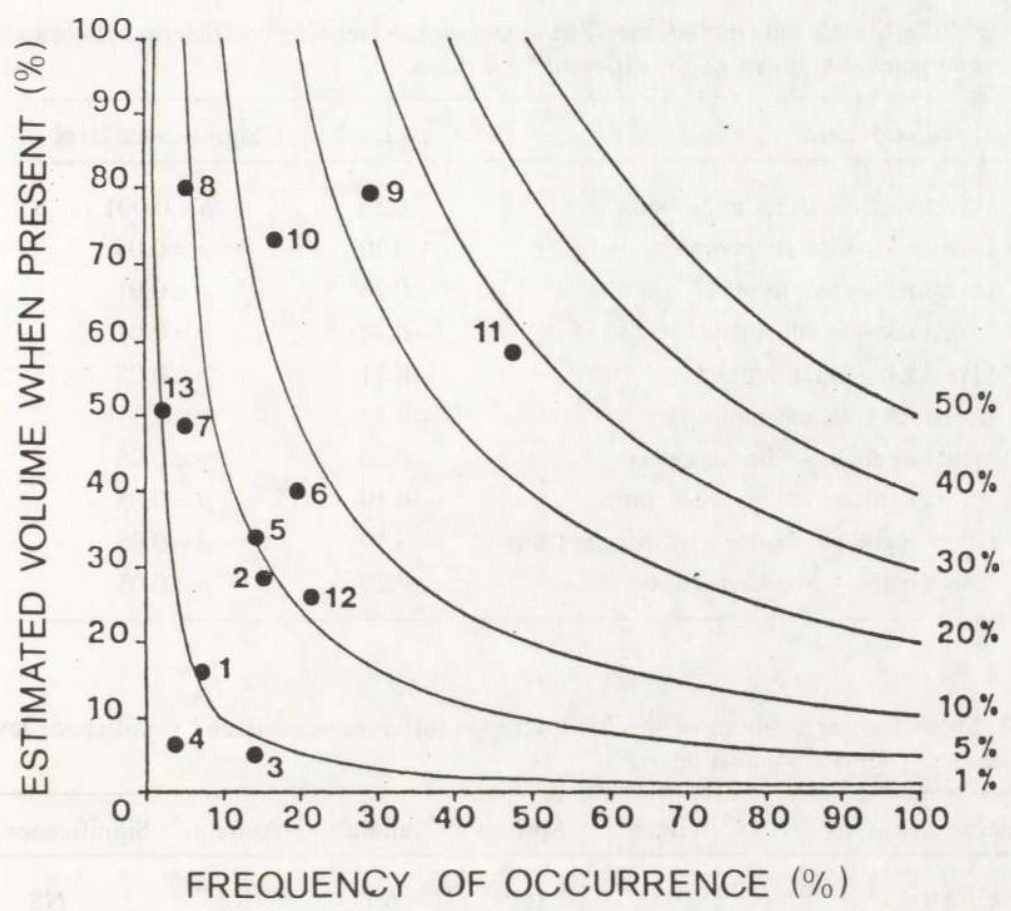

Fig. 2. Estimated bulk food item whenever it was eaten, versus frequency of occurrence all year round. Isopleths connect points of equal relative bulk in the overall diet of the wolf (i.e. percent volume in total diet; Kruuk and Parish 1981). 1 - earthworms, 2 - grasshoppers, 3 -Coleoptera, 4 -other arthropods, 5 -insectivores, 6 - small rodents, 7 - lagomorphs, 8 - carnivores, 9 - livestock, 10 - wild ungulates, 11 - Rosaceae fruits, 12 - other vegetable matter, 13 - garbage.

Coleoptera and other arthropods) were the least important food type. Garbage had the lowest value of occurrence. The mean percent volume of livestock and wild ungulates were negatively correlated and both were negatively correlated with some other items (Table 2). Insectivores and other arthropods were positively correlated.

The seasonal diets significantly differed for the presence of grasshoppers, Coleoptera, Rosaceae fruits and livestock (Table 3). The greatest number of significant differences in the presence of these items was recorded between spring and autumn (Table 4). Overall seasonal diets were little diversified, and the greatest overlap was recorded between winter and spring (Table 5). The diet breadth was at maximum in spring and decreased in summer and autumn (Table 6).

We recorded 45 cases of predation on livestock during the research: 17 calves, 3 foals and 25 sheep. Comparison with availability of domestic prey showed selection for sheep and avoidance of calves ( $p<0.05$ in both cases). The period of predation on livestock was from June to September. Calves were preyed in all four months (max. in July) while sheep only in August and September (Fig. 3). 
Table 2. Significant correlations (Spearman rank correlation coefficient) between mean percent volumes of the different food items.

\begin{tabular}{lrc}
\hline \multicolumn{1}{c}{ Food items } & $\mathrm{r}_{\mathbf{s}}$ & Significance level \\
\hline Insectivores - Other arthropods & 0.35 & $p<0.001$ \\
Livestock - Grasshoppers & -0.19 & $p=0.05$ \\
Livestock - Insectivores & -0.26 & $p<0.01$ \\
Livestock - Small rodents & -0.24 & $p=0.01$ \\
Livestock - Wild ungulates & -0.21 & $p<0.05$ \\
Livestock - Rosaceae fruits & -0.43 & $p<0.001$ \\
Wild ungulates - Grasshoppers & -0.20 & $p<0.05$ \\
Wild ungulates - Rosaceae fruits & -0.19 & $p=0.05$ \\
Other vegetable matter - Rosaceae fruits & -0.19 & $p=0.05$ \\
Insectivores - Rosaceae fruits & 0.20 & $p<0.05$ \\
\hline
\end{tabular}

Table 3. Mean percent volumes of the food items in different seasons and significance level of the differences (Kruskall-Wallis test).

\begin{tabular}{lccccc}
\hline Food items & Winter & Spring & Summer & Autumn & Significance level \\
\hline Earthworms & 0.0 & 0.7 & 6.1 & 0.1 & NS \\
Grasshoppers & 0.2 & 0.9 & 1.1 & 13.1 & $p=0.01$ \\
Coleoptera & 0.1 & 0.7 & 1.8 & 0.6 & $p=0.05$ \\
Other arthropods & 0.1 & 0.2 & 0.0 & 0.5 & NS \\
Insectivores & 4.6 & 7.8 & 2.7 & 2.5 & NS \\
Small rodents & 7.4 & 4.9 & 2.7 & 6.5 & NS \\
Lagomorphs & 4.4 & 0.5 & 4.5 & 2.1 & NS \\
Livestock & 14.3 & 9.0 & 44.0 & 38.0 & $p<0.01$ \\
Wild ungulates & 16.6 & 10.7 & 14.0 & 10.7 & NS \\
Foxes & 4.4 & 5.9 & 7.0 & 0.0 & NS \\
Rosaceae fruits & 34.3 & 39.0 & 12.4 & 18.7 & $p=0.01$ \\
Other vegetable matter & 11.4 & 6.5 & 0.3 & 3.4 & NS \\
Garbage & 0.0 & 3.1 & 0.0 & 0.0 & NS \\
\hline
\end{tabular}

Table 4. Comparison between seasonal values of the mean percent volume for the food items with significant seasonal variations (Mann-Whitney $U$-test). W - winter, S - spring, Su. - summer, A - autumn.

\begin{tabular}{lcccccc}
\hline Food items & W $-\mathrm{S}$ & W-Su. & W-A & S-Su. & S - A & Su. -A \\
\hline Grasshoppers & NS & NS & $p<0.05$ & NS & $p=0.01$ & NS \\
Coleoptera & NS & p $<0.05$ & NS & NS & NS & $p<0.05$ \\
Livestock & NS & NS & NS & $p<0.01$ & $p<0.01$ & NS \\
Rosaceae fruits & NS & $p<0.05$ & NS & $p=0.01$ & $p=0.01$ & NS \\
\hline
\end{tabular}


Table 5. Overlap between seasonal diets (C - index, Goszczyński 1986).

\begin{tabular}{llcc}
\hline Seasons & Winter & Spring & Summer \\
\hline Spring & 0.94 & & \\
Summer & 0.72 & 0.63 & \\
Autumn & 0.79 & 0.73 & 0.80 \\
\hline
\end{tabular}

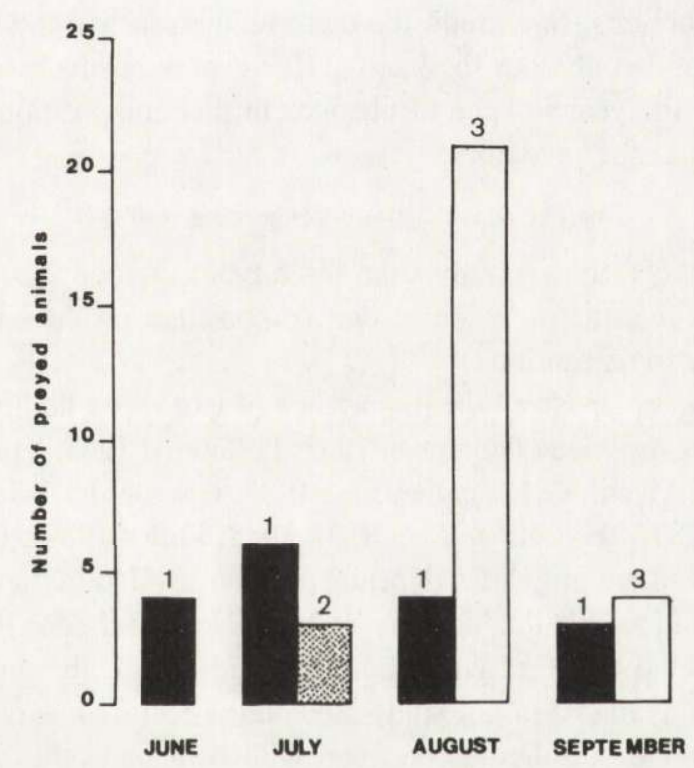

Table 6. Seasonal value of the diet breadth (B -index, Feisinger et al. 1981).

\begin{tabular}{lc}
\hline Seasons & B \\
\hline Winter & 0.528 \\
Spring & 0.610 \\
Summer & 0.510 \\
Autumn & 0.495 \\
\hline
\end{tabular}

Fig. 3. Predations on different species of livestock during the grazing period. 1 - calves, 2 - foals, 3 - sheep.

\section{Discussion}

\section{Habitat use and diet}

Habitat use and the breadth of the area exploited by terrestrial predators is conditioned by factors such as food availability and quality, and weather (Goszczyński 1986b).

In winter all the observations were recorded in lower altitude areas characterized by a southern exposure and reduced snow cover. These zones were mainly used by potential prey species such as wild boar and hares (pers. obs.). We observed the presence of wild boar mainly in conifer reafforestations and of hares in pastures and in shrub, the habitats selected by wolves in winter.

Scat analyses showed that the presence of wild boar and hares in the diet increased in winter. The food needs of wolves in winter were satisfied by Rosaceae fruits (mainly Rosa 
canina) that are widely present in bushy areas and preserved by low temperatures during the winter. In spring, availability of the most suitable prey (large mammals) very low in our study area; thus the wolves must use a greater number of food items and diet breadth increases. Rosaceae fruits were again the most important item, as the most used habitat was the shrub $(\mathrm{PI}=36.3)$. In summer the observations were mainly located on and around the ridges in relation to the presence of livestock grazing on the pastures on the ridges. Livestock can be considered the main food of wolves in summer because of the high energetic and protein requirements of the rearing pups. In autumn the main food items in the diet of the wolves were livestock and grasshoppers, which can easily be found in pastures, wild boar that in this season frequented mixed woods to feed on chestnuts and acorns, and Rosaceae fruits which were widespread in woods, fields and its borders. In autumn the diet breadth reached the minimum value of the year and diet was based on only four food items. However only small variations were recorded in diet breadth during the year in spite of changes in diet composition, showing that wolves in our zone are opportunistic predators.

\section{Further considerations concerning wolf diet}

In our study area the wolves mainly used three types of food: Rosaceae fruits, livestock and wild boar; though the interpretation of diet composition on the basis of our sample size should be treated with some caution.

Several studies have emphasized the importance of large wild herbivores in wolf diet both in Europe and in North America (Thompson 1952, Pulliainen 1965, Voigt et al. 1976, Guitian et al. 1979, Fritts and Mech 1981, Brana et al. 1982, Grande del Brio 1984, Okarma 1984, Salvador and Abad 1987, Reig and Jędrzejewski 1988, Fuller 1989). Other researchers have found that wolf predation on ungulates depends on their availability and that inclusion in the wolf diet of other prey is related to a decrease in ungulate populations (Cowan 1947, Stenlund 1955, Kuyt 1972, Mech 1977, Carbyn 1983). The wild boar is the only species of ungulate present and plentifully available in our study area and it occurred as prey all year round with small variations. Negative correlations between wild boar and other food items in the dict showed a high suitability value of this prey.

The energy and protein requirements of wolves were satisfied by predation on livestock in summer and autumn during the grazing period (negative correlations between livestock presence in diet and other food items). Livestock predation by wolves is well documented by various studies on feeding habits (Pulliainen 1965, Castroviejo et al. 1981, Fritts and Mech 1981, Gunson 1983, Bjorge and Gunson 1983, Tompa 1983, Reig et al. 1985) but it seems that livestock, despite its vulnerability, is an alternative prey where wild ungulates are not very abundant. In our study area also the negative correlations recorded between livestock and wild boar showed that the two prey items tend to be mutually exclusive. Within livestock species wolves selected sheep if the proportion of predation for the different species is compared to availability, but predations on sheep occurred only in late summer and autumn. At the beginning of grazing period wolves preyed only on calves. In late summer calves are not available as prey because after the first two weeks of life they are included in the herds that exert an active defence against predators (pers. obs.). On the contrary sheep are always easy to take because of their small size, especially if they are not watched, as in our study area. Selection for 
particular domestic ungulate species was recorded also in other study areas, and sheep and calves seem to be the preferred prey species in most cases (Pulliainen 1965, Castroviejo et al. 1981, Gunson 1983, Tompa 1983). The occurrence of livestock remnants in scats out of the grazing period was probably due to lost animals and to carcasses of animals that had died of natural causes. The presence of fruit in the wolf diet has been described by several authors. In North America the occurrence of this food item is in general very low (see for example Thompson 1952, Van Ballenberghe et al. 1975, Fritts and Mech 1981) and it seems to occur mainly in pup scats in summer. In Europe fruits were recorded in the diet of wolves in Spain (Castroviejo et al. 1981, Salvador-Abad 1987), in central Italy (Boitani 1982, Ragni et al. 1982, Matteucci 1987) and in Finland (Pulliainen 1965). In our study both the frequency and the volume of fruit (Rosaceae) were the highest ever recorded, especially in seasons when livestock are not present on pastures. However, skin and stones of these fruits are very poorly digested, and in spite of the fact that they can be found frequently and in large amounts in scats, they are not probably the most important item from the energetic point of view. In other regions of South Europe, where large herbivores are not abundant, wolves feed on garbage. This important food source is scarcely available in northern Italy so that wolves are obliged to use other resources as Rosaceae fruits. These fruits are very abundant in our study area because of the abandonment of pastures and cultivated fields.

Other less important food items (small rodents, insects, etc.) can complete the diet enabling the wolves to survive in less favourable seasons.

The similarity of the seasonal diets was very high; only spring and summer diets were well differentiated, because of the change from a frugivorous to a carnivorous regimen.

In conclusion the presence of wolves in northern Italy is only partially dependent on food sources of human origin, but these are of fundamental importance during the period of pup rearing.

Acknowledgements: The authors thank the provinces of Piacenza and Alessandria for financial support; L. Boitani, S. Lovari, H. Okarma and an anonymous referee for useful comments on the manuscript and F. Barbieri and L. Canova for their help in field work.

\section{References}

Apollonio M., Randi E. and Toso S. 1988. The systematics of the wild boar (Sus scrofa L.) in Italy. Boll. Zool. 55: $213-221$.

Bibikov D. I., ed. 1985. The wolf. History, systematics, morphology, ecology. Nauka. Moscow: 1 - 606. [In Russian]

Bjärvall A. 1983. Scandinavia's response to a natural repopulation of wolves. Acta Zool. Fenn. 174: 273 - 275.

Bjorge R. R. and Gunson J. R. 1983. Wolf predation of cattle on the Simonette River pastures in northwestern Alberta. [In: Wolves in Canada and Alaska. L. N. Carbyn, ed.] Can. Wildl. Serv. Rep. Ser. 45: 106 - 111.

Boitani L. 1981. Il Lupo. [In: Distribuzione e biologia di 22 specie di mammiferi in Italia. M. Pavan, ed.]. CNR, Roma: $61-68$.

Boitani L. 1982. Wolf management in intensively used areas of Italy. [In: Wolves of the world. Perspectives of behavior, ecology and conservation. F. H. Harrington and P. C. Pacquet, eds]. Noyes, Park Ridge: 158 - 172.

Boitani L. 1983. Wolf and dog competition in Italy. Acta Zool Fenn. 174: 259-264.

Brana F., Del Campo J. C. and Palomero G. 1982. Le Loup dans la Cordillère Cantabrique. Acta Biol. Montana 1: $33-52$.

Brunner H. and Coman B. J. 1974. The identification of mammalian hair. Inkata Press, Melbourne. 
Byers C. R., Steinhorst R. K. and Krausman P. R. 1984. Clarification of a technique for analysis of utilization -availability data. J. Wildl. Manage. 48: $1050-1053$.

Cagnolaro L., Rosso D., Spagnesi M. and Venturi D. 1974. Inchiesta sulla distribuzione del lupo in Italia e nei cantoni Ticino e Grigioni. Ric. Biol. Selv. 61.

Carbyn L. N. 1983. Wolf predation on elk in Riding Mountain National Park Manitoba. J. Wildl. Manage. 47: $963-976$.

Castroviejo J., Palacios F., Garzon J. and Cuesta L. 1981. Sobre la alimentacion de los canides ibericos. Proc. XIIth IUGB Congr. Lisboa, 1975.

Cowan I. M. 1947. The timber wolf in the Rocky Mountain National Park in Canada. Can. J. Res. 25: 139 - 174.

Debrot S., Fivaz G., Mermod C. and Weber J. M. 1982. Atlas des poils de mammiféres d'Europe. Peseux: Imprimerie de l'Ouest S.A.

Feisinger P., Spers E. E. and Poole R. W. 1981. A simple measure of niche breadth. Ecology 62: $27-32$.

Fritts S. H. and Mech L. D. 1981. Dynamics, movements, and feeding ecology of a newly protected wolf population in northwestern Minnesota. Wildl. Monogr. 80: 1 - 79.

Fuller T. K. 1989. Population dynamics of wolves in North-Central Minnesota. Wildl. Monogr. 105: 1-41.

Fuller T. K. and Sampson B. A. 1988. Evaluation of a simulated howling survey for wolves. J. Wildl. Manage. 52: $60-63$.

Genov P. 1987. The wolf (Canis lupus L.) in southwest Bulgaria. [In: Abstracts of the XVIIIth IUGB Congr., B. Bobek , K. Perzanowski, W.L. Regelin and R. Tertil, eds]. Jagiellonian University, Kraków: 66.

Goszczyński J. 1986a. Diet of foxes and martens in central Poland. Acta theriol. 31: 491 - 506.

Goszczyński J. 1986b. Locomotor activity of the terrestrial predators and its consequences. Acta theriol. 31: $79-95$.

Grande del Brio R. 1984. El lobo iberico. Biologia y mitologia, Madrid: H. Blume.

Guitian J., De Castro A., Bas S. and Sanchez J. L. 1979. Nota sobre la dieta del lobo (Canis lupus) en Galicia. Trb. Comp. Biol. 14: 95 - 104.

Gunson J. R. 1983. Wolf predation of livestock in western Canada. [In: Wolves in Canada and Alaska. L. N. Carbyn, ed.]. Can Wildl. Serv. Rep. Ser. 45: 102 - 105.

Harrington F. H. and Mech L. D. 1982. An analysis of howling response parameters useful for wolf pack censusing. J. Wildl. Manage. 46: $686-693$.

Horn M. S. 1966. Measurement of "overlap" in comparative ecological studies. Am. Nat. 100: 419-424.

Kruuk H. and Parish T. 1981. Feeding specialization of the European badger (Meles meles) in Scotland. J. Anim. Ecol. 50: 773 - 788 .

Kuyt E. 1972. Food habits of wolves on barren ground caribou range. Can. Wildl. Serv. Rept. Ser. 21: 1 - 36.

Matteucci C. 1987. Preliminary data on the ecology of a wolf (Canis lupus L.) population in northern Italy. [In: Abstracts of the XVIIIth IUGB Congr. B. Bobek, K. Perzanowski, W. L. Regelin and R. Tertil, eds]. Jagiellonian University, Kraków: 117.

Mech L. D. 1977. Population trend and winter deer consumption in a Minnesota wolf pack. [In: Proc. 1975 Predator Symposium. R. Phillips and C. Jonkel, eds]. Univ. Montana, Missoula: 55 - 83.

Neu C. W., Byers C. R. and Peek J. M. 1974. A technique for analysis of utilization-availability data. J. Wildl. Manage. 38: $541-545$.

Okarma H. 1984. The physical condition of red deer falling prey to the wolf and lynx and harvested in the Carpathian Mountains. Acta theriol. 29: 283-290.

Okarma H. 1989. Distribution and numbers of wolves in Poland. Acta theriol. 34: $497-503$.

Pulliainen E. 1965. Studies on the wolf (Canis lupus) in Finland. Ann. Zool. Fenn. 2: 215 - 259.

Pulliainen E. 1985. The expansion mechanism of the wolf (Canis lupus) in northern Europe. Rev. Ecol. (Terre Vie) 40: $157-162$.

Ragni B., Mariani A., Inverni I. and Magrini M. 1982. Il lupo in Umbria. [In: Atti del Conv. Naz. "Gruppo Lupo Italia. G. Boscagli, ed.]. Gruppo Lupo Italia, Pescasseroli: 22 - 36.

Reig S., De La Cuesta L. and Palacios F. 1985. The impact of human activities on the food habits of red fox and wolf in old Castille, Spain. Rev. Ecol. (Terre Vie) 40: 151 - 157. 
Reig S., De La Cuesta L., Barcena F. and Palacios F. 1987. Status of the wolf in Spain. [In: Abstracts of the XVIIIth IUGB Congr. B. Bobek, K. Perzanowski, W. L. Regelin and R. Tertil, eds]. Jagiellonian University, Kraków: 163 - 164 .

Reig S. and Jędrzejewski W. 1988. Winter and early spring food of some camivores in Białowieża National Park, eastern Poland. Acta theriol. 33: 57 - 65.

Robel R. J., Briggs J. N., Cebula J. J., Silvy N. J., Viers C.E. and Watt P. G. 1970. Greater prairie chiken ranges, movements, and habitat usage in Kansas. J. Wildl. Manage. 34: 286 - 306.

Salvador A. and Abad P. L. 1987. Food habits of a wolf population in Leon province, Spain. Mammalia 51: $45-52$.

Stenlund M. H. 1955. A field study of the timber wolf (Canis lupus) on the Superior National Forest, Minnesota. Minn. Dept. Cons. Tech. Bull. 4: 1 - 55 .

Strickland D. 1983. Wolf howling in parks - the Algonquin experience in interpretation. [In: Wolves in Canada and Alaska. L. N. Carbyn ed.]. Can. Wildl. Serv. Rep. Ser. 45: 93 - 95.

Thompson D. Q. 1952. Travel, range, and food habits of timber wolves in Wisconsin. J. Mammal. 33: 429 - 442.

Tompa F. S. 1983. Problem wolf management in British Columbia: conflict and program evaluation. [In: Wolves in Canada and Alaska. L. N. Carbyn, ed.]. Can. Wildl. Serv. Rep. Ser. 45: 112 - 119.

Van Ballenberghe V., Erickson A. W. and Byman D. 1975. Ecology of the timber wolf in northeastern Minnesota. Wildl. Monogr. 43: 1 - 43.

Voigt D., Kolenosky G. B. and Pimlott D. H. 1976. Changes in summer food of wolves in Central Ontario. J. Wildl. Manage. 40: $663-668$.

Vóskar J. 1983. Present problem of wolf conservation in Czechoslovakia. Acta Zool. Fenn. 174: 287 - 288.

Zimen E. and Boitani L. 1975. Number and distribution of wolves in Italy. Z. Säugetierk. 40: 102 - 112.

\begin{tabular}{lcc}
\hline Appendix 1. Food species and items detected by analysis of wolf scats. & \\
\hline Earthworms & Small rodents & Rosaceae fruits \\
Lumbricus sp. & Sciurus vulgaris & Rosa canina \\
Grasshoppers & Glis glis & Malus sp. \\
Undet. grasshoppers & Muscardinus avellanarius & Pirus sp. \\
Grillus sp. & Clethrionomys glareolus & Prunus sp. \\
Coleoptera & Pitymys sp. & Sorbus sp. \\
Undet. Coleoptera & Apodemus sp. & Rubus sp. \\
Carabus sp. & Mus musculus & Other vegetable matter \\
Undet. Carabidae & Lagomorphs & Undet. vegetable matter \\
Geotrupes stercorarius & Lepus europaeus & Juniperus communis \\
Sylpha carenata & Carnivores & Corylus avellana \\
Other arthropods & Vulpes vulpes & Fagus sylvatica \\
Undet. larvae & Livestock & Castanea sativa \\
Insectivores & Equus caballus & Juglans regia \\
Sorex sp. & Bos taurus & Vitis vinifera \\
Crocidura sp. & Ovis aries & Undet. Graminaceae \\
Talpa sp. & Capra aegagrus hircus & Garbage \\
Neomys sp. & Wild ungulates & \\
& Sus scrofa &
\end{tabular}

Received 14 March 1991, accepted 10 July 1991. 